\title{
Article
}

\section{Morphological Study of Length, Breadth and Thickness of the Ovary at Different Age Group in Bangladeshi People}

\begin{abstract}
Ahmed SM${ }^{1}$, Khalil $\mathbf{M}^{2}$, Rahman $\mathrm{MH}^{3}$, Mannan $\mathrm{S}^{4}$, Sultana $\mathrm{SZ}^{5}$, Ara $\mathrm{ZG}^{6}$, Rahman $\mathrm{MM}^{7}$
The morphological study was done to see length, breadth and thickness of the ovary in different age group of Bangladeshi people to increase the knowledge regarding variational anatomy in our population. Sixty two postmortem tissue block containing ovary and fallopian tube along with surrounding structures were collected from 62 female cadavers of different age groups and fixed in $10 \%$ formol saline solution. Gross \& fine dissections were carried out to study these morphological parameters of ovary in different age group. In the present study, findings were compared with the finding of other researchers.

In this study the mean length of ovary was maximum in found in group C (46-80 years) $4.32 \mathrm{~cm}$ and minimum was found in group A (2-13 years) $2.81 \mathrm{~cm}$ of both side. The mean breadth of ovary was maximum in group C $2.01 \mathrm{~cm}$ and minimum was in group A $1.38 \mathrm{~cm}$. The mean thickness of ovary maximum was in group $C 0.971 \mathrm{~cm}$ and minimum was in group A $0.682 \mathrm{~cm}$ of both sides. In statistical analyses significant difference between two groups was calculated by using students " $\mathrm{t}$ " test. A difference between two groups was considered to be significant when $p<0.05$. In the present study it is observed that the size of the ovary is not equal on both side of same individual.
\end{abstract}

Key Words: Ovary; Morphology; Bangladesh

J Bangladesh Soc Physiol. 2007 Dec;(2):24-27.

For author affiliations, see end of text.

http://www.banglajol.info/index.php/JBSP

\section{Introduction}

$\Gamma$ he ovaries are a pair of female reproductive and endocrine glands ${ }^{1}$. The ovaries of the female are
homologous with the testis of the male. They are solid, nodular bodies, with the proportions of a large unshelled almond. Situated on either side of the uterus, behind and below the uterine tubes. They are attached to the back of the broad ligament and to the lateral wall of the lesser pelvis by peritoneal folds. The ovaries contains numerous ova, which are discharged during ovulation by periodic rupture of the follicles; in addition to being cytogenic glands, the ovaries produce hormones regulatory of the development and activity of the female reproductive organs ${ }^{2}$. Reproduction is basic part of human life cycle to

J Bangladesh Soc Physiol. 2007 Dec;(2): 24-27 maintain its own species. The ovaries are the organs responsible for the production of the female germ cells, the ova and the female sex hormones, estrogen and progesterone in the sexually mature female ${ }^{3}$. Without maintaining these functions properly by ovaries, life will be burdensome. For these reason, ovary is one of the essential sexual organ in human being. To understand the basic mechanism of these important functions of human body has an immerse value. Now a day, large numbers of people are suffering from ovarian disease and also importance for diagnostic as well as surgical purposes. So a research work on detailed anatomical parameters such as length, breadth and thickness of ovary is an un-debatable 
requirement for the successful treatment of ovarian disease.

\section{Methods}

The present study was performed on 62 post mortem human ovaries from Bangladeshi female cadaver's age ranging from 02 to 80 years. All specimens were studied by careful gross dissection. Specimens containing ovaries with ligament, uterus and fallopian tube were collected from dead bodies autopsied on different dates from October 2006 to May 2007 at the autopsy laboratory of Department of Forensic Medicine of Mymensingh Medical College, Mymensingh, Bangladesh.

All the collected specimens were from medicolegal cases. Only fresh specimen of ovaries was selected from the dead bodies which were collected within 24 hours after death. Ovaries of decomposed body grossly injured and poisonous cases were excluded from the study. The collected specimens were tagged with an identifying number representing individual serial number. The particulars of the body (age and cause of death) were the respective specimen number. Undergoing the study 62 ovaries were divided into three categories e.g. 2-13 years in group A, 14-45 years in group B and 46-80 years in group $\mathrm{C}$.

The study was carried out in the Department of Anatomy, Mymensingh Medical College, Mymensingh, Bangladesh between July 2006 to June 2007. From each cadaver the ovary and fallopian tubes and related neighboring structures were collected by “Block Dissection” during routine post mortem examination. Then the collected specimens were washed gently with tap water to remove the blood and blood clots as per as possible.

The specimens were fixed and preserved in 10\% formol saline solution. Gross and fine dissection J Bangladesh Soc Physiol. 2007 Dec;(2): 24-27 was carried out to study the length, breadth and thickness of the ovary after removing the ligament of the ovary. The length, breadth and thickness of ovary were measured with the help of a slide caliper. The lengths of ovaries were measured from its upper pole to lower pole. The breadth and thickness were measured in the middle portion of the ovaries.

All the data were recorded in pre-designed data sheet from specimen of each cadaver. The collected data were processed and analyzed statistically by ANOVA to find out the significance difference in different age groups.

\section{Results}

Comparison of length of ovary in three age groups. are shown in Table I. In this study difference of mean length of ovaries between group A vs. group B and group B vs. group C were statistically significant on both side but the difference between group A vs. C of right ovary highly significant and left ovary moderately significant only.

Table I : Depicts length of ovary in different age groups

\begin{tabular}{|c|c|c|}
\hline Groups & $\begin{array}{c}\text { Length of } \\
\text { right ovary }(\mathrm{cm}) \\
\text { mean } \pm \mathrm{SE}\end{array}$ & $\begin{array}{c}\text { Length of } \\
\text { left ovary }(\mathrm{cm}) \\
\text { mean } \pm \mathrm{SE}\end{array}$ \\
\hline A(2-13 years) & $2.81 \pm 0.52$ & $2.50 \pm 0.42$ \\
\hline B(14-45 years) & $3.64 \pm 0.92$ & $3.50 \pm 0.78$ \\
\hline C(46-80 years $)$ & $4.15 \pm 0.53$ & $4.32 \pm 0.83$ \\
\hline \multicolumn{3}{|c|}{ statistical analysis } \\
\hline \multirow[t]{2}{*}{ Groups } & \multicolumn{2}{|c|}{ Level of significance } \\
\hline & Right ovary & Left ovary \\
\hline A vs. B & Significant & Significant \\
\hline B vs. C & Significant & Significant \\
\hline A vs. C & $\begin{array}{c}\text { Highly } \\
\text { significant }\end{array}$ & $\begin{array}{l}\text { Moderately } \\
\text { significant }\end{array}$ \\
\hline
\end{tabular}




\section{Article}

Table - II: Shows morphological characters of ovaries in different age groups

\begin{tabular}{lcc}
\hline Groups & $\begin{array}{c}\text { Breadth } \\
\text { (mean) } \pm \text { SE } \\
\text { of right ovary } \\
\text { in cm }\end{array}$ & $\begin{array}{c}\text { Breadth } \\
\text { (mean) } \pm \text { SE } \\
\text { of left ovary } \\
\text { in cm }\end{array}$ \\
\hline $\mathrm{A}(2-13$ years) & $1.45 \pm 0.42$ & $1.38 \pm 0.35$ \\
$\mathrm{~B}$ (14-45 years) & $1.88 \pm 0.46$ & $1.88 \pm 0.51$ \\
$\mathrm{C}$ (46-80 years) & $2.01 \pm 0.46$ & $1.67 \pm 0.47$ \\
\hline
\end{tabular}

Statistical analysis

\begin{tabular}{lcc}
\hline Groups & \multicolumn{2}{c}{ Level of significance } \\
& Right ovary & Left ovary \\
\hline A vs. B & Significant & Significant \\
B vs. C & Significant & Not significant \\
A vs. C & Highly significant & Significant \\
\hline
\end{tabular}

Comparison of breadth of ovary in there age groups A, B \& C are shown in Table-II. The average breadth of right ovary was maximum in group $\mathrm{C}$ and minimum in group $\mathrm{B}$.

The average breadth of left ovary was maximum in group B and minim in group A. In statistical analysis the difference mean breadth of ovary between A vs. B was only significant on both side but difference between A vs. C was highly significant on right side and significant only on the left side.

Thickness of ovaries in different age groups is shown in Table III. In present study maximum thickness of right ovary was in group $\mathrm{C}$ and minimum was found in group A but in case of left ovary maximum thickness of ovary was found in group B and minimum in group $\mathrm{A}$.

In statistical analysis the mean thickness of difference between group A vs. B was highly significant on both sides. In case of B vs. C was significant only on right side.

The thickness difference between group A vs. C was significant on both sides.
Morphology of Ovary

Table - III: Thickness of ovaries in different age groups

\begin{tabular}{lcc}
\hline Groups & $\begin{array}{c}\text { Thickness } \\
\text { (mean) } \pm \text { SE } \\
\text { of right ovary } \\
\text { in cm }\end{array}$ & $\begin{array}{c}\text { Thickness } \\
\text { (mean) } \pm \text { SE } \\
\text { of left ovary } \\
\text { in cm }\end{array}$ \\
\hline A(2-13 years) & $0.682 \pm 0.15$ & $0.709 \pm 0.08$ \\
B(14-45 years) & $0.877 \pm 0.29$ & $0.951 \pm 0.28$ \\
C(46-80 years) & $0.971 \pm 0.17$ & $0.814 \pm 0.23$ \\
\hline \multicolumn{3}{c}{ Statistical analysis } \\
\hline Groups & Level of significance \\
\hline A vs. B & Right ovary & Left ovary \\
B vs. C & Highly & Highly \\
A vs. C & Significant & Significant \\
\hline
\end{tabular}

\section{Discussion}

The ovary shows considerable individual variation in size and the right is considerable, some what larger than the left. The mean length, breadth and thickness were more on right side than left which was confirmed to the findings of McVay. He found the length, breadth and thickness of the ovary were $3.6 \mathrm{~mm}$ in length, $1.8 \mathrm{~cm}$ in breadth and $1.2 \mathrm{~cm}$ in thickness ${ }^{2}$ which is less than my finding.

Where as Thomas Ind. ${ }^{4}$ found length, breadth and thickness were $2.0 \mathrm{~cm}, 1.5 \mathrm{~cm}$, and $0.5 \mathrm{~cm}$ in early menopause and $1.5 \times 7.5 \times 0.5 \mathrm{~cm}$ which is very less than my finding. Sinnatambly ${ }^{5}$ states that the ovaries are somewhat flattened, ovoid bodies, measuring about $3 \mathrm{~cm}$ in length, $2 \mathrm{~cm}$ in width and $1 \mathrm{~cm}$ in thickness ${ }^{5}$, which is less than my findings.

Copenhaver ${ }^{6}$ found that the length, breadth and thickness were $4.0 \mathrm{~cm}, 2.0 \mathrm{~cm}$ and $1.0 \mathrm{~cm}$ which are similar with my findings in $\mathrm{C}$ group.

In this study it is observed that the size of the ovary is not equal in both side of the same individual.

Our present finding indicates that length, breadth and thickness of ovary are more than the other researchers.

J Bangladesh Soc Physiol. 2007 Dec;(2): 24-27 
It is expected that, the findings of the present study will enrich the information pool on the morphology of ovary in different age group in Bangladeshi people.

\section{Author Affiliation}

1. *Dr Md Shibbir Ahmed, Lecturer of Anatomy, Mymensingh Medical College, Mymensingh, Bangladesh

2. Prof. Mohsin Khalil, Professor and Head of Anatomy, Mymensingh Medical College, Mymensingh, Bangladesh

3. Dr Md Habibur Rahman, Assistant Professor, Anatomy Department, Mymensingh Medical College, Mymensingh, Bangladesh

4. Dr Sabina Mannan, Assistant Professor (CC) of Anatomy, Mymensingh Medical College, Mymensingh, Bangladesh

5. Dr Seheli Zannat Sultana, Assistant Professor of Anatomy, Mymensingh Medical College, Mymensingh, Bangladesh

6. Dr Zubaida Gulshan Ara, Assistant Professor, Department of Anatomy, CBMCB, Mymensingh, Bangladesh

7. Dr M Mahbubur Rahman, MBBS, M Phil, Lecturer of Anatomy, Mymensingh Medical College, Mymensingh, Bangladesh

* For correspondence

\section{References}

1. Datta AK. Essential of Human Anatomy Part II. $6^{\text {th }}$ ed. Calcutta Current Book International; 2003. p. 315-31.

2. McVay A. Surgical Anatomy (Volume-2). $5^{\text {th }}$ ed. Philadelphia: WB Saunders Company; 1971. p. 805-06.

3. Snell RS. Clinical anatomy. $7^{\text {th }}$ ed. Baltimore: Lippincott William and Wilkins; 2004. p. 386-90.

4. Thomas Ind. Editor. Female reproductive system. In: Standring S, Ellis H, Healy JC, Tohnson D, Williams A, Collins P, Wigley C. Editors. Gray’s Anatomy: The Anatomical Basis of Clinical Practice. $39^{\text {th }}$ ed. Edinburgh: Elsevier Churchill Livingstone; 2005. p. 1332-38.

5. Sinnatambly CS. Last's anatomy. Regional and Applied. $10^{\text {th }}$ ed. Churchill, Livingstone. 1999. p. 296-98.

6. Copenhaver MW, Bunge RP, Bunge MD. Bailey’s text book of Histology. $16^{\text {th }}$ ed. Baltimore: The William and Wilkins Company; 1971. p. 581-92. 